\title{
PENGARUH BUMBU PADA KEPITING BAKAU (Scylla olivacea) TERHADAP KANDUNGAN LOGAM TIMBAL (Pb)
}

\author{
Alfian Effendy ${ }^{1}$ Hening Widowati ${ }^{2}$ Suharno Zen ${ }^{3}$ \\ 1,2,3 Program Studi Pendidikan Biologi, Universitas Muhammadiyah Metro \\ 1 alfianeffendy4@gmail.com, ${ }^{2}$ hwummetro@gmail.com, ${ }^{3}$ suharnozein@gmail.com
}

\begin{abstract}
Abstrak: Bumbu mengandung antioksidan alami yang dapat menangkal radikal bebas dalam tubuh. Radikal bebas dapat ditimbulkan oleh zat pencemar yang masuk kedalam tubuh manusia. Limbah logam berat timbal $(\mathrm{Pb})$ merupakan zat pencemar yang berbahaya bagi tubuh manusia jika terkontaminasi dalam jumlah kadar tertentu. Limbah $\mathrm{Pb}$ dapat masuk kedalam tubuh melalui makanan yang dikonsumsi. Kepiting bakau memiliki potensi yang besar dapat tercemar logam timbal karena habitatnya berada di daerah hilir yang menerima pasokan limbah dari hulu. Penelitian ini bertujuan untuk mengetahui apakah terdapat pengaruh bumbu terhadap kandungan $\mathrm{Pb}$ dalam daging kepiting bakau. Sampel daging kepiting bakau diambil dari tambak Pasir Sakti Lampung Timur. Penelitian ini merupakan penelitian eksperimen dengan Rancangan Acak Lengkap (RAL). Penelitian ini menggunakan 4 perlakuan, 1 sebagai kontrol dan 3 perlakuan dengan variasi bumbu yang berbeda (5, 10, dan 12 jenis bumbu). Masing-masing perlakuan memiliki 8 ulangan. Kemudian sampel dianalisis kandungan $\mathrm{Pb}$ menggunakan metode spektrofotometer uv-vis. Berdasarkan hasil analisis statistik, Fhit > Fdaf $(25,27>2,95)$ maka $\mathrm{H} 0$ ditolak sehingga dapat disimpulkan bahwa terdapat pengaruh perlakuan variasi bumbu terhadap kandungan $\mathrm{Pb}$ pada daging kepiting bakau.
\end{abstract}

Kata kunci: antioksidan, kepiting bakau (Scylla olivacea), logam timbal ( $\mathrm{Pb})$

\begin{abstract}
Abstrack: Spices contain natural antioxidants that can counteract free radicals in the body. Free radicals can be generated by pollutants that enter the human body. Heavy metal waste lead $(P b)$ is a pollutant that is harmful to the human body if it is contaminated in certain levels. Pb waste can enter the body through the food consumed. Mangrove crab has a great potential to be contaminated with lead metal because its habitat is in a downstream area that receives a supply of waste from upstream. This study aims to determine whether there is an effect of seasoning on the Pb content in mud crab meat. Mangrove crab meat samples were taken from Pasir Sakti ponds, East Lampung. This research is an experimental study with a completely randomized design (CRD). This study used 4 treatments, 1 as a control and 3 treatments with different variations of spices (5, 10, and 12 types of spices). Each treatment had 8 replications. Then the samples were analyzed for Pb content using the uv-vis spectrophotometer method. Based on the results of statistical analysis, Fhit > Fdaf (25.27 > 2.95) then $\mathrm{HO}$ is rejected so it can be concluded that there is an effect of spice variation treatment on the $\mathrm{Pb}$ content in mud crab meat.
\end{abstract}

Keywords: antioxidant, mud crab (Scylla olivacea), lead metal $(\mathrm{Pb})$

How to Cite

Effendy, Alfian, Hening Widowati, Suharno Zen. 2022. Pengaruh Bumbu pada Kepiting Bakau (Scylla olivacea) Terhadap Kandungan Logam Timbal (Pb), Biolova 3(1) . 6-12. 
Provinsi Lampung memiliki kawasan minapolitan yang terletak di Kecamatan Pasir Sakti Kabupaten Lampung Timur berdasarkan Keputusan Menteri Kelautan dan Perikanan Nomor 35 Tahun 2013 (Mulyanto, dkk., 2018). Menurut penelitian Widowati, dkk., (2021) terdapat komoditas budidaya tambak berupa kepiting bakau yang tercemar logam timbal $(\mathrm{Pb})$ di tambak Pasir Sakti. Sumber cemaran logam timbal $(\mathrm{Pb})$ di tambak dapat berasal dari pipapipa air, pestisida, insektisida, dan moluskisida.

Susilawati, dkk., (2021) menyatakan bahwa kandungan logam timbal $(\mathrm{Pb})$ pada daging udang vaname tambak tradisional jauh mangrove di Pasir Sakti Kabupaten Lampung Timur rata-rata mencapai 523,65 ppb. Kepiting bakau yang dibudidayakan pada lokasi yang sama berpotensi ikut terkontaminasi logam timbal (Pb). Purnamasari, dkk., (2014) menyimpulkan bahwa kepiting bakau di Sungai Donan Cilacap mengandung logam timbal $(\mathrm{Pb})$ antara 4,735 -448,611 ppm dengan rata-rata sebesar 61,808 ppm. Sedangkan batas maksimum cemaran logam berat $(\mathrm{Pb})$ dalam pangan olahan menurut BPOM (Badan Pengawas Obat dan Makanan) nomor 5 tahun 2018 untuk pangan jenis udang dan krustasea lain adalah sebesar $200 \mathrm{ppb}$ atau $0,2 \mathrm{mg} / \mathrm{kg}$. Hasil penelitian Purnamasari menunjukkan bahwa kepiting bakau mampu mengakumulasi logam timbal $(\mathrm{Pb})$ dan bahkan melebihi batas maksimum cemaran logam berat $(\mathrm{Pb})$ dalam pangan olahan.

Timbal $(\mathrm{Pb})$ merupakan salah satu dari logam berat yang dapat mencemari lingkungan sekitar. Limbah cair timbal $(\mathrm{Pb})$ yang dibuang ke perairan akan mengakibatkan limbah larut dalam perairan sehingga banyak makhluk hidup yang terkontaminasi zat pencemar. Adapun sebagian limbah timbal $(\mathrm{Pb})$ padat seperti sisa-sisa cat kapal dengan cepat akan turun kedalam dasar perairan dan mengendap dalam sedimen serta mencemari substrat sedimen sekitar perairan (Stephany, dkk, 2018). Limbah timbal $(\mathrm{Pb})$ yang terbuang di daerah perairan akan terbawa arus dari hulu menuju ke hilir, sehingga limbah timbal dapat mencemari tempat budidaya perairan yang berada di hilir seperti tambak.

besar $\begin{array}{r}\text { Kepiting bakau berpeluang } \\ \text { mengakumulasi }\end{array}$ termasuk logam timbal $(\mathrm{Pb})$. Hal tersebut disebabkan karena kepiting bakau bersifat menetap berada pada suatu tempat, dimana kepiting bakau hidup di daerah hilir yang menerima pasokan dari daerah hulu seperti limbah logam timbal $(\mathrm{Pb})$. Kepiting bakau dapat bertahan lama didalam air ataupun lumpur berpasir, sehingga apabila perairan, makanan, ataupun substrat yang ditempati kepiting bakau telah tercemar maka kepiting bakau berpotensi besar akan ikut terkontaminasi oleh zat pencemar.

Logam berat seperti timbal $(\mathrm{Pb})$ di lingkungan sekitar dapat menyebabkan keracunan pada sel-sel hidup seperti tumbuh-tumbuhan, hewan, dan manusia (Juhri, 2017). Kandungan logam berat di dalam daging kepiting bakau jika dikonsumsi pada kadar berlebih dapat menyebabkan keracunan bagi manusia. Manusia sebagai hamba Allah SWT diperintahkan supaya memilih makanan yang halal dan baik, sebagai mana firman Allah SWT dalam Al-quran surat Al-baqarah ayat 168.

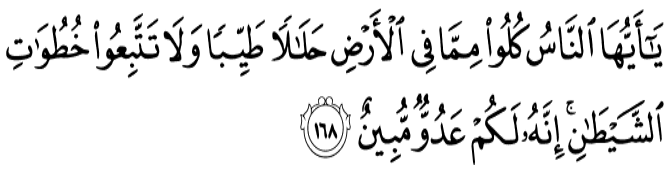

Artinya: Hai sekalian manusia, makanlah yang halal lagi baik dari apa yang terdapat di bumi, dan janganlah 
kamu mengikuti langkah-langkah setan; karena sesungguhnya setan itu adalah musuh yang nyata bagimu. (Q.S. Al-baqarah: 168).

Al-Qur'an surat Al-baqarah ayat 168 menunjukkan bahwa Allah SWT. memerintahkan kepada hambanya supaya memakan pada makanan yang halal dan baik/thayyib. Manusia diperintahkan untuk menjaga kesehatan melalui konsumsi makanan yang sehat. Perintah ini begitu relevan karena gangguan kesehatan selalu disebabkan oleh pola makan seseorang.

Memilih makanan yang halal dan baik berdasarkan pengkajian uji laboratorium merupakan salah satu upaya merealisasikan visi lembaga Universitas Muhammadiyah Metro yaitu "Pusat Keunggulan Profetik Profesional, Modern dan Mencerahkan" sehingga tertanam pada diri peserta didik sifat profesional profetis yang sidiq (jujur), amanah (bisa dipercaya), fathonah (pintar/cerdas), dan tablegh (mengkomunikasikan sesuatu yang benar). Dengan memilih untuk mengkonsumsi makanan yang sehat menandakan bahwa orang tersebut bersifat fathonah (pintar/cerdas).

Berdasarkan visi lembaga Universitas Muhammadiyah Metro maka sebagai pribadi yang fathonah tentunya supaya berfikir kritis bagaimana upaya untuk meminimalisir atau menanggulangi kadar logam berat timbal $(\mathrm{Pb})$ pada daging kepiting bakau yang tercemar. Perlu diketahui bagaimana cara memanfaatkan bumbu yang tepat dalam mengolah kepiting bakau agar mengurangi kadar polutan apabila terkandung dalam daging kepiting bakau walaupun hanya sedikit. Setiap olahan kepiting bakau memiliki rasio bumbu/rempah yang berbeda, hal ini akan menghasilkan cita rasa masakan yang khas berbeda, dan diasumsikan mempengaruhi kerja antioksidan dalam bumbu/rempah yang menetralkan radikal bebas logam berat $\mathrm{Pb}$ di dalam daging kepiting bakau.

Logam berat seperti timbal $(\mathrm{Pb})$ dapat menimbulkan radikal bebas dalam tubuh. Antioksidan dapat menangkal radikal bebas yang disebabkan oleh logam timbal (Kamilatussaniah, dkk., 2015). Antioksidan bekerja dengan cara mendonorkan satu elektronnya kepada senyawa yang bersifat oksidan sehingga aktivitas senyawa oksidan tersebut bisa terhambat. Antioksidan menstabilkan radikal bebas dengan melengkapi kekurangan elektron yang dimiliki radikal bebas, dan menghambat terjadinya reaksi berantai dari pembentukan radikal bebas sehingga antioksidan berfungsi untuk mengatasi atau menetralisir radikal bebas dan melindungi sel dari radikal bebas (Malangngi, dkk. 2012).

Tujuan penelitian ini adalah untuk mengetahui pengaruh penggunaan bumbu pada kepiting bakau (Scylla olivacea) terhadap kandungan logam timbal $(\mathrm{Pb})$ ".

\section{METODE}

A. Jenis Penelitian

Penelitian ini merupakan penelitian eksperimen, dengan Rancangan Acak Lengkap (RAL). Penelitian ini menggunakan 4 perlakuan, 1 sebagai kontrol dan 3 perlakuan dengan variasi bumbu yang berbeda yaitu: perlakuan A (5 jenis bumbu), perlakuan B (10 jenis bumbu), dan perlakuan C (12 jenis bumbu). Masing-masing perlakuan memiliki 8 ulangan.

Data yang diperoleh dianalisis dengan menggunakann uji ANAVA satu arah. Adapun syarat dilakukan pengujian menggunakan ANAVA yaitu apabila data tersebut berdistriusi normal dan homogen, apabila data 
tersebut normal dan homogen maka dilakukan uji ANAVA satu arah.

\section{B. Alat dan Bahan}

Sampel daging kepiting bakau yang digunakan untuk masing-masing ulangan sebanyak 400 gram. Total populasi daging kepiting bakau yang di gunakan yaitu sebanyak $1,6 \mathrm{~kg}$.

Alat yang digunakan adalah: wajan, presto, ember, baskom, nampan, peniris, timbangan, sutil, pisau, gunting, talenan, plastik, steroform, kertas label, botol sampel.

Bahan yang digunakan dalam penelitian yaitu: kepiting bakau $1,6 \mathrm{~kg}$, Jeruk nipis $1 \mathrm{~kg}$, bawang merah $1 \mathrm{~kg}$, bawang putih $1 / 2 \mathrm{~kg}$, cabe merah $1 / 2 \mathrm{~kg}$, cabe rawit hijau $1 / 4 \mathrm{~kg}$, cabe rawit merah $1 / 4 \mathrm{~kg}$, tomat $1 / 2 \mathrm{~kg}$, jahe $1 / 4 \mathrm{~kg}$, kunyit $1 / 4 \mathrm{~kg}$, daun salam $11 \mathrm{gr}$, sereh $73 \mathrm{gr}$, daun jeruk 3 ikat, daun pandan 3 ikat, daun kunyit 3 ikat, daun bawang 3 ikat, daun kemangi 3 ikat, ketumbar, dan kemiri.

\section{Tahapan Penelitian}

Tahapan yang dilakukan dalam penelitian ini adalah sebagai berikut:

1. Menentukan tempat pengambilan sampel, dalam penelitian ini lokasi pengambilan sampel adalah di Tambak Tradisional Pasir Sakti Lampung Timur.

2. Menentukan ukuran sampel yang akan diambil dari keseluruhan anggota, sampel yang digunakan untuk masing-masing ulangan sebanyak 400 gram.

3. Membersihkan dan menimbang sampel.

4. Sampel kepiting bakau diolah menggunakan 3 macam perlakuan yaitu perlakuan A (5 jenis bumbu), perlakuan B (10 jenis bumbu), dan perlakuan $\mathrm{C}$ (12 jenis bumbu). Langkah-langkahnya yaitu dengan melumuri daging kepiting dengan air jeruk nipis selama 15 menit, mengkukus kepiting selama 10 menit, dan merebus kepiting bakau dengan bumbu yang telah dihaluskan selama 5 menit.

5. Kepiting yang telah diolah, ditimbang sekitar 400 gram tiap sampelnya, dimasukkan botol container, ditutup rapat dengan lakban, dan dibekukan dalam freezer kulkas. Setelah beku, pada pagi harinya dimasukkan dalam kotak steroform untuk dikirim ke laboratorium kimia Universitas Muhammadiyah Malang untuk dianalisis sesuai parameter yang ditentukan (kadar logam berat timbal). Metode untuk mengukur kadar logam timbal pada penelitian ini yaitu dengan menggunakan Spektrofotometer UV-Vis.

\section{HASIL}

Tabel 1. Rata-rata Hasil Analisis Kadar Timbal $(\mathrm{Pb})$

\begin{tabular}{|c|c|}
\hline Perlakuan & Rata-rata (ppb) \\
\hline Kontrol & 256,8 \\
\hline Perlakuan A & 197,6 \\
\hline Perlakuan B & 175,3 \\
\hline Perlakuan C & 148,4 \\
\hline
\end{tabular}

\section{PEMBAHASAN}

Berdasarkan BPOM nomor 5 tahun 2018, batas maksimum cemaran logam timbal dalam pangan olahan jenis udang dan krustasea lain adalah $200 \mathrm{ppm}$ atau $0,2 \mathrm{mg} / \mathrm{kg}$. Berdasarkan data hasil penelitian, perlakuan kontrol (tanpa variasi bumbu) menunjukkan kadar logam timbal yang belum melebihi batas maksimum cemaran logam timbal dalam pangan yaitu $256,8 \mathrm{ppb}$. Walaupun demikian tetap perlu adanya upaya untuk mengurangi kadar logam timbal dengan memanfaatkan bumbu atau rempahrempah.

Perlakuan A memiliki variasi 5 jenis bumbu yaitu cabe rawit, cabe merah, bawang merah, tomat, dan daun kemangi. Nilai rata-rata kadar 
timbal daging kepiting bakau perlakuan kontrol (tanpa perlakuan) yaitu 256,8 ppb, sedangkan nilai kadar timbal daging kepiting bakau perlakuan A yaitu sebesar 197,6 ppb. Selisih nilai kadar timbal perlakuan kontrol dan perlakuan A mencapai 59,2 ppb, sehingga persentase penurunan kadar logam timbal pada perlakuan A yaitu 23,05\%.

Perlakuan B memiliki variasi 10 jenis bumbu yaitu cabe rawit, cabe merah, bawang merah, tomat, daun kemangi, daun bawang, serai, daun jeruk, bawang putih, dan jahe. Nilai rata-rata kadar timbal daging kepiting bakau perlakuan kontrol (tanpa perlakuan) yaitu $256,8 \mathrm{ppb}$, sedangkan nilai kadar timbal daging kepiting bakau perlakuan B yaitu sebesar 175,3 ppb. Selisih nilai kadar timbal perlakuan kontrol dan perlakuan B mencapai 81,5 ppb, sehingga persentase penurunan kadar logam timbal pada perlakuan $B$ yaitu $31,74 \%$.

Perlakuan $\mathrm{C}$ memiliki variasi 12 jenis bumbu yaitu cabe rawit, cabe merah, bawang merah, tomat, daun kemangi, daun bawang, serai, daun jeruk, bawang putih, jahe, daun pandan, dan kemiri. Nilai rata-rata kadar timbal daging kepiting bakau perlakuan kontrol (tanpa perlakuan) yaitu 256,8 ppb, sedangkan nilai kadar timbal daging kepiting bakau perlakuan C yaitu sebesar 148,4 ppb. Selisih nilai kadar timbal perlakuan kontrol dan perlakuan $\mathrm{C}$ mencapai 108,4 ppb, sehingga persentase penurunan kadar logam timbal pada perlakuan C yaitu $42,21 \%$.

Perlakuan variasi bumbu pada kepiting bakau (Scylla olivacea) terhadap kandungan logam timbal $\mathrm{Pb})$ dengan pengaruh terbaik adalah pada perlakuan $\mathrm{C}$ (variasi 12 jenis bumbu). Dalam perlakuan variasi 12 jenis bumbu (perlakuan C) mencakup jenis bumbu yang ada di perlakuan $\mathrm{A}$ dan B. Berdasarkan hasil penelitian, variasi dengan jumlah jenis bumbu terbanyak adalah yang paling tinggi dalam menurunkan kadar logam timbal dalam daging kepiting bakau.

Bumbu memiliki senyawa antioksidan, salah satunya adalah senyawa flavonoid. Senyawa flavonoid merupakan golongan senyawa fenolik, bersifat polar, dan dapat larut dalam air. Senyawa flavonoid dapat mengikat senyawa logam sehingga terbentuk senyawa kompleks yang lebih stabil. Selly (2018: 22) menyatakan bahwa radikal $\mathrm{FeS}$ atau besi (II) sulfide merupakan molekul senyawa hasil reaksi unsur Fe dan S. Radikal ini memiliki dua elektron bebas, sehingga memerlukan donor dua elektron dari antioksidan. Donor elektron memungkinkan untuk terbentuknya senyawa baru, seperti $\mathrm{Fe} 2+$ dan $\mathrm{Fe} 3+$. Oleh karena itu, diperlukan radikal chelator untuk mengikat $\mathrm{Fe} 2+$ dan $\mathrm{Fe} 3+$ sehingga terbentuk senyawa kompleks yang lebih stabil dan tidak menjadi sumber radikal baru.

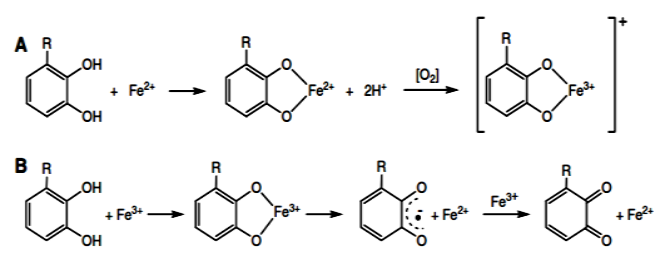

Gambar 1. Reaksi Pengikatan Logam oleh Senyawa Flavonoid.

Aktivitas bivalensi yaitu ionisasi 2 ion $\mathrm{H}+$ dari senyawa timbal(II) atau $\mathrm{Pb} 2+$ sama dengan $\mathrm{Fe} 2+$, maka reaksi senyawa antioksidan dalam pengikatan $\mathrm{Pb} 2+$ akan sama dengan Fe2+. Timbal(II) atau $\mathrm{Pb} 2+$ memiliki 2 ion $\mathrm{H}+$ seperti $\mathrm{Fe} 2+$, sehingga memerlukan donor dua elektron lagi. Berdasarkan gambar 2 diatas, maka senyawa antioksidan mampu mengikat $\mathrm{Pb} 2+$ dan akan membentuk senyawa kompleks yang lebih stabil. 


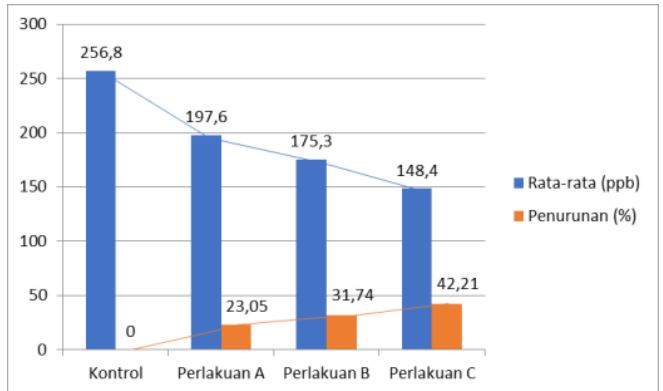

Gambar 2. Rata-rata Kadar Pb dan

Persentase Penurunan Kadar

$\mathrm{Pb}$

Berdasarkan hasil analisis statistik, didapatkan Fhitung $>$ Fdaftar $(25,27>2,95)$ dengan dk pembilang $(\mathrm{k}-1)=3$ dan $\mathrm{dk}$ penyebut $\mathrm{k}(\mathrm{r}-1)=28$ maka $\mathrm{H} 0$ ditolak sehingga dapat disimpulkan bahwa terdapat pengaruh perlakuan variasi bumbu terhadap kandungan logam timbal pada daging kepiting bakau.

\section{KESIMPULAN}

Berdasarkan data hasil penelitian yang telah dilakukan dapat disimpulkan bahwa variasi bumbu pada kepiting bakau (Scylla olivacea) berpengaruh terhadap kandungan logam timbal $(\mathrm{Pb})$. Perlakuan $\mathrm{C}$ dengan 12 jenis bumbu (cabe rawit, cabe merah, bawang merah, tomat, daun kemangi, daun bawang, serai, daun jeruk, bawang putih, jahe, daun pandan, dan kemiri) memiliki pengaruh terbaik dalam menurunkan kadar logam timbal $(\mathrm{Pb})$ dengan persentase sebesar $42,21 \%$.

\section{SARAN}

Saran berdasarkan hasil penelitian yang telah dilakukan yaitu perlunya penelitian lebih lanjut mengenai mekanisme antioksidan dari berbagai bumbu lokal dalam menurunkan kadar logam selain timbal.

\section{DAFTAR RUJUKAN}

Badan Pengawas Obat dan Makanan (BPOM). 2018. Batas Maksimum Cemaran Logam Berat dalam Pangan Olahan. Jakarta. h.3.

Juhri, D. A. (2017). Pengaruh Logam Berat (Kadmium, Kromium, dan Timbal) terhadap Penurunan Berat Basah Kangkung Air (Ipomoea aquatica Forsk) sebagai Bahan Penyuluhan Bagi Petani Sayur. Jurnal Lentera Pendidikan Pusat Penelitian Lppm Um Metro, 2(2), 219-229.

Kamilatussaniah, K., Yuniastuti, A., \& Iswari, R. S. 2015. Pengaruh Suplementasi Madu Kelengkeng terhadap Kadar Tsa dan Mda Tikus Putih yang di Induksi Timbal (Pb). Indonesian Journal of Mathematics and Natural Sciences, 38(2), 108-114.

Malangngi, L., Sangi, M., \& Paendong, J., 2012. Penentuan Kandungan Tanin dan Uji Aktivitas Antioksidan Ekstrak Biji Buah Alpukat (Persea americana Mill.). Jurnal MIPA, 1(1), 5-10.

Mulyanto, R. T., Sumadi, S., \& Miswar, D. 2018. Evaluasi Kesesuaian Lahan Tambak Menggunakan Aplikasi Sistem Informasi Geografi di Kecamatan Labuhan Maringgai. JPG (Jurnal Penelitian Geografi), 6(8).

Purnamasari, V. N., Widiyanto, A. F., \& Kuswanto, K. 2014. Analisis Kandungan Timbal $(\mathrm{Pb})$ dan Laju Konsumsi Aman pada Kepiting Bakau (Scylla serrata Forskal) di Sungai Donan 
Cilacap. Kesmas Indonesia, 6(3), 157-165.

Selly, J. B. 2018. Efektifitas Ekstrak Faloak (Stercullia quadrifida R. Br) sebagai Chelator bagi Radikal FeS Akibat Pencemaran Logam Timbal. CHMK Health Journal, 2(2), 23-23.

Stephany, H., Diansyah, G., \& Putri, W. A. E. 2018. Analisis Logam Berat Timbal $(\mathrm{Pb})$ pada Air dan Sedimen di Kolam Perairan Pelabuhan Tanjung Priok, Jakarta Utara. Doctoral dissertation, Sriwijaya University. Hal. 7.

Susilawati, D. 2021. Pengaruh Variasi Perendaman Udang Vaname (Litopenaeus vannamei) dalam Asam Buah Alami terhadap Penurunan Kadar Timbal $(\mathrm{Pb})$ di Tambak Tradisional Pasir Sakti Lampung Timur. BIOLOVA, 2(2), 134-143.

Widowati, H., Sutanto, A., \& Sulistiani, W. S. 2021. Pengembangan Minapolitan Pasir Sakti dalam Memanfaatkan Produk Utama dan Sampingan Tambak Udang Secara Berkelanjutan melalui Pemberdayaan Potensi Kearifan Lokal. SNPPM-3 (Seminar Nasional Penelitian dan Pengabdian kepada Masyarakat). ISBN 978-62390328-7-6. h. 279 
